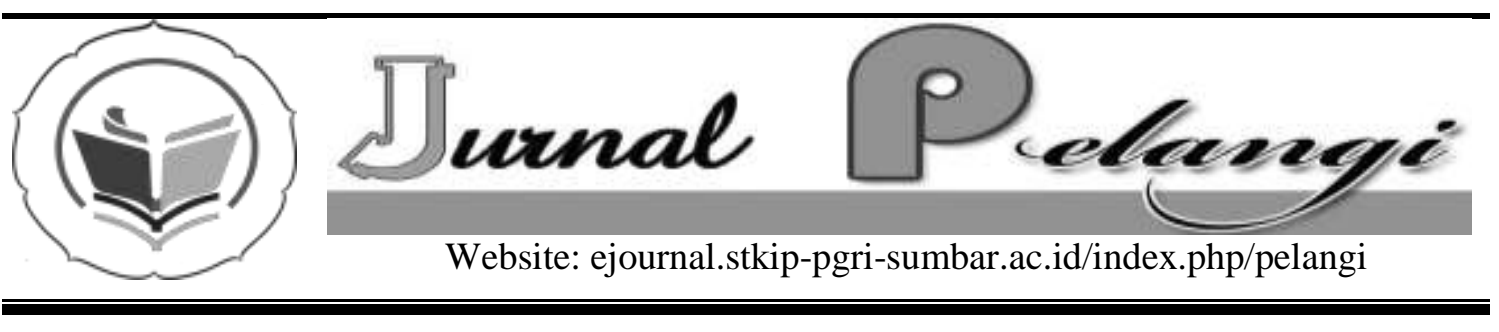

\title{
ANALISIS PERILAKU MASYARAKAT DALAM PENGELOLAAN LINGKUNGAN DISEPANJANG DAERAH ALIRAN SUNGAI BATANG KURANJI
}

\author{
Aslan Sari Thesiwati
}

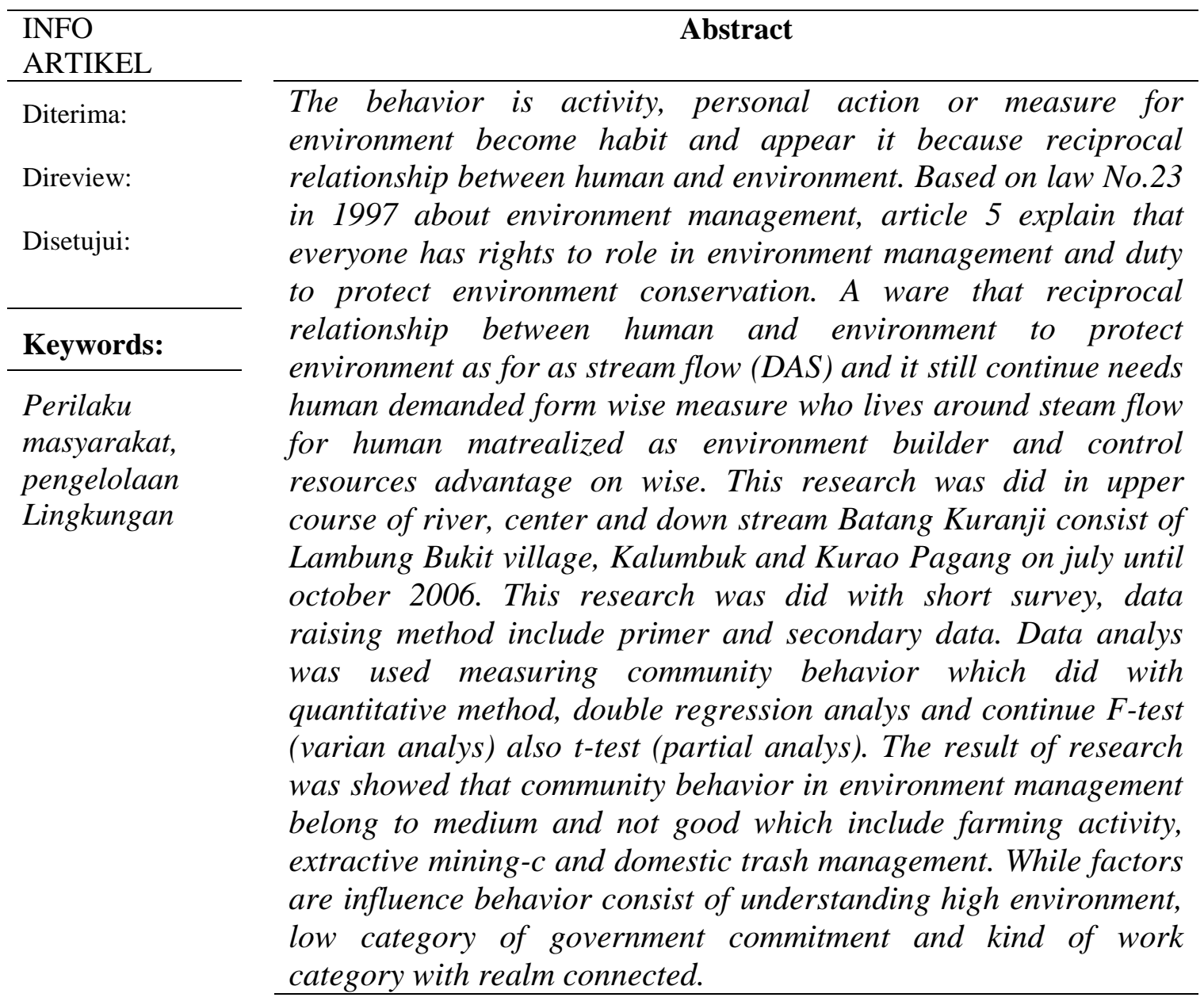




\section{PENDAHULUAN}

Kota Padang mempunyai enam daerah aliran sungai (DAS) yaitu: Batang Kandis, Batang Arau, Batang Kuranji, Batang Air Dingin, Batang Timbulan dan Batang Anak Pisang dengan luas keseluruhan kawasan DAS 69.496 Ha. Kota Padang yang terletak di dataran Alluvial yang terbentuk atas tiga aliran sungai utama yaitu: Sungai Batang Arau, Batang Kuranji, dan Batang Air Dingin dengan daerah tangkapan hujan yang bersumber dari Gunung Bolak, Gunung Lantik dan Gunung Bongsu.

Salah satu kawasan DAS yang perlu mendapat perhatian khusus adalah Sungai Batang Kuranji. Sungai ini mempunyai peran penting dalam kehidupan sehari-hari karena mempunyai fungsi: (1) ekologi yaitu habitat bagi organisme perairan dan daerah tangkapan air (catchment area), (2) sosial yaitu sumber air bersih dan baku masyarakat dan (3) ekonomi yaitu sumber air untuk irigasi Berdasarkan Undang-Undang No. 24 Tahun 1992 dalam pasal 7 ayat 1 , tentang penataan ruang yang menyatakan, sempadan sungai termasuk dalam kawasan lindung. Saat sekarang di sepanjang daerah aliran sungai telah terjadi alih guna fungsi lahan, berdasarkan undang-undang diatas kawasan sempadan sungai berjarak $100 \mathrm{~m}$ kiri-kanan sungai tidak boleh mendirikan bangunan dan melakukan aktivitas pemanfaatan lahan.

Adanya kenaikan jumlah pertumbuhan penduduk tahun $2000 \mathrm{~s} / \mathrm{d}$ tahun 2004. Terlihat pada Kecamatan Kuranji dan Kecamatan Pauh sebagai kecamatan yang berada di sepanjang DAS Batang Kuranji, mengalami peningkatan angka pertumbuhan penduduk, untuk Kecamatan Kuranji $(3,38 \%)$ dan Kecamatan Pauh $(3,99 \%)$ rata-rata per tahun. Penyebab tingginya kerapatan penduduk sepanjang kawasan aliran sungai Batang Kuranji karena adanya perkembangan pembangunan fisik (pemukiman) dan usaha sehingga menarik minat masyarakat untuk bermukim di bantaran sungai, kondisi lahan yang cocok untuk kegiatan pertanian dan adanya sumber daya alam yang dapat di eksploitasi sebagai mata pencaharian penduduk setempat. hasil observasi adanya perilaku rumah tangga yang membuang sampah, kegiatan eksploitasi bahan galian-c dan adanya penerapan teknologi pertanian intensif yang menekankan pada pemupukan berat dengan menggunakan pupuk anorganik dan pestisida dengan tujuan peningkatan produksi tinggi dalam waktu yang relatif singkat. Perilaku masyarakat dalam pemanfaatan kawasan Perilaku ini jika dibiarkan akan menimbulkan dampak seperti: masalah kesuburan tanah, mencemari lingkungan, dan mengganggu kesehatan manusia.

Berdasarkan Undang-Undang No.23 Tahun 1997 pasal 1 ayat 2, tentang pengelolaan lingkungan menyatakan, bahwa usaha pengelolaan lingkungan merupakan upaya terpadu dalam melestarikan fungsi lingkungan yang meliputi kebijakan penataan, pemanfaatan, pengembangan, pemeliharaan, pemulihan dan pengawasan lingkungan dan pasal 5 menyatakan, bahwa setiap orang berhak untuk berperan dalam pengelolaan lingkungan dan berkewajiban memelihara kelestarian fungsi lingkungan, mencegah dan menanggulangi pencemaran serta perusakan lingkungan.

Menyadari adanya hubungan timbal-balik antara lingkungan dengan manusia, maka untuk menjaga lingkungan sepanjang daerah aliran sungai tetap lestari dituntut perilaku yang bijak dan kepedulian dari seluruh masyarakat yang tinggal di sekitar aliran sungai serta perhatian pemerintah dalam bentuk penyediaan sarana dan prasarana, 
bimbingan serta pengawasan terhadap setiap aktivitas pembangunan. Dalam rangka mewujudkan, menumbuhkan, meningkatkan kesadaran masyarakat dan tercapainya keselarasan hubungan antara manusia dan lingkungan serta terciptanya manusia sebagai pembina lingkungan.

\section{METODE PENELITIAN}

Lokasi penelitian ditentukan dengan cara sengaja (purposive) dengan pertimbangan sebagai berikut: 1 . Lambung Bukit ( I ) mewakili daerah kegiatan pertanian sawah dan ladang yang lebih luas dibandingkan daerah lain (masyarakat bertani $331 \mathrm{KK}$ berdasarkan kantor Kecamatan Pauh, 2004). Kalumbuk (II) mewakili daerah melakukan kegiatan penambangan bahan galian-c dalam bentuk pasir, batu dan kerikil pada badan sungai. 3. Kurao Pagang (III) merupakan daerah pemukiman yang berhubungan langsung dengan kawasan bantaran aliran sungai dengan tingkat kepadatan penduduk lebih tinggi dibanding daerah lain.

Penelitian ini dilaksanakan dengan pendekatan survei, yang difokuskan pada bagaimana perilaku masyarakat dalam upaya pemanfaatan lahan pada daerah aliran sungai Batang kuranji, yang nantinya mempengaruhi pengelolaan lingkungan pada DAS Batang Kuranji. Kuestioner dengan daftar pertanyaan dimaksudkan untuk memperoleh data berupa jawaban tertulis dari responden. Wawancara mendalam dilakukan dengan informan. Data sekunder diperoleh dari literatur-literatur yang ada baik dari instansi pemerintah Analisis regresi berganda ini pengolahan datanya dilakukan dengan menggunakan program Software Statistical Product and Service Solution (SPSS) versi 10,0 windows.

\section{HASIL PENELITIAN}

4.1. Gambaran Umum Wilayah Daerah Aliran Sungai Batang Kuranji Daerah aliran sungai Batang Kuranji secara geografis terletak pada $00^{\circ} 48^{\prime}$ $00^{\circ} 56^{\prime} \mathrm{LU}$ dan $100^{\circ} 20^{\prime}-100^{\circ} 34^{\prime} \mathrm{BT}$. Wilayah yang tercakup DAS Kuranji dari hulunya dibatas kota Padang dengan Kabupaten Solok sampai garis pantai barat Sumatera, yang mencakup lima kecamatan yaitu: Kecamatan Pauh, Kuranji, Nanggalo, Padang Utara dan Koto Tangah dengan ketinggian dari permukaan laut $1.858 \mathrm{~m} \mathrm{dpl} \mathrm{-} 94.9 \mathrm{~m}$ dpl dan luas $22.251 \mathrm{Ha}$ ( Dinas Kimpraswil Kota Padang, 2004).

DAS Batang Kuranji mempunyai bentuk dan lereng yang sangat bervariasi mulai dari klas datar, lereng, bukit sampai curam dan daerah yang cukup datar berada pada bagian hilir. Dengan pola penggunaan lahan pada DAS Batang Kuranji didominasi untuk pertanian, hutan dan pemukiman dimana penggunaan lahan tersebar berada pada bagian tengah dan hilir aliran sungai. (Survei Pusat Studi Irigasi, Sumberdaya Air, Lahan dan Pembangunan Universitas Andalas, 2004).

Batang Kuranji merupakan salah satu aliran sungai utama yang berhulu dari Gunung Sikai dan kemudian mengalir ke daerah selatan melalui sungai Limau Manis. Ada beberapa anak sungai yang bermuara ke sungai Batang Kuranji meliputi sungai: Padang Janiah, Padang Karuah, dan Limau Manis pada daerah hulu dan sungai Kubu Gadang, Balimbing dan Laras pada bagian hilir. Daerah kawasan hulu daearah aliran sungai Batang Kuranji berada pada wilayah Kelurahan Lambung Bukit Kec.Pauh. Sementara daerah yang dikatakan bagian tengah mencakup kelurahan lain dari Kec. Pauh dan sebagian kelurahan dari Kec. Kuranji. Sedangkan daerah hilir meliputi sebagian Kec. Kuranji, Kec. Nanggalo dan Kec.Padang Utara. 


\subsection{Perilaku Masyarakat Dalam Pengelolaan Lingkungan \\ 4.2.1. Perilaku Masyarakat Dalam kegiatan Pertanian}

Pola usaha pertanian kelurahan Lambung Bukit pada umumnya adalah usaha sawah dengan komoditi padi $(80 \%)$ dan pola pertanian lainnya yakni ladang dengan komoditi sayur-sayuran dan palawija (Survei Pusat Studi Irigasi, Sumberdaya Air, Lahan dan Pembangunan Universitas Andalas, 2004). Perilaku responden dalam kegiatan pertanian yang diamati adalah kegiatan berkaitan dengan tindakan pemupukan dan pemberantasan hama.

a. Kegiatan Pemupukan dan pemberantasan hama Mayoritas Responden (65,22\%) menggunakan pupuk anorganik dalam bercocok tanam. Survei lapangan dimana petani lebih menyukai penggunaan pupuk anorganik yang digalakkan oleh petugas penyuluh pertanian dibandingkan pupuk organik. Berdasarkan penjelasan ketua kelompok tani Tanus Muda Firdaus Djabar menyatakan bahwa,"Umumnya masyarakat tani disini cenderung menggunakan pupuk buatan karna pupuk buatan dalam penggunaan lebih efektif dan efisien pemberian untuk tanaman". Dari mayoritas responden yang menggunakan pupuk buatan sesuai dengan petunjuk penggunaan.

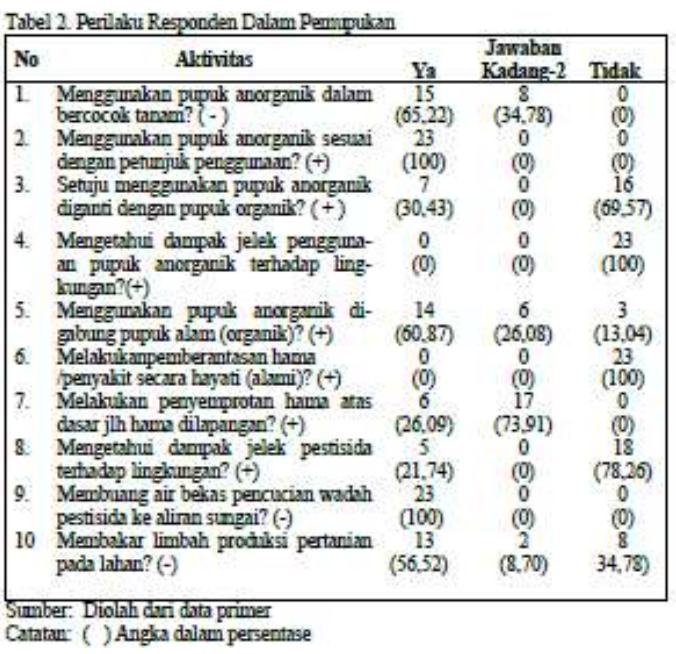

jumlah pupuk yang diperlukan dengan kebutuhan hara tanaman, hara yang diberikan dalam bentuk yang cepat tersedia, dapat diberikan pada waktu yang tepat dan lebih mudah dalam pemakaian dan pengangkutan serta kadar haranya yang tinggi (Hakim, Nyakpa, Lubis, Nugroho, Saul, Diha, Homh, dan Bailey, 1986). Hal ini didukung $(69,57 \%)$ responden menjawab tidak setuju jika menggunakan pupuk anorganik diganti pupuk organic. Namun petani menyadari, harga pupuk anorganik yang mahal sehingga untuk komoditi tertentu, seperti: sayuran para petani $\quad(86,95 \%) \quad$ cenderung menggabungkan pupuk anorganik dan organik.

Pemupukan berat dengan pupuk anorganik menyebabkan sebagian pupuk tidak terpakai menumpuk di dalam tanah. Penumpukan pupuk ini akan berdampak negatif terhadap lingkungan terutama pupuk nitrat dan fosfat dalam bentuk anion yang tidak diabsorbsi oleh liat akan menjadi polutan pada lingkungan perairan (Tan, 1996). Ditambahkan Hakim et al (1986), kelemahan pupuk an-organik bila tidak diperhitungkan dalam pemakaiannya maka penggunaannya dapat merusak lingkungan. Dalam konsep penggunaanya, pestisida adalah alternatif terakhir apabila cara pengendalian lain tidak memberikan hasil yang memuaskan. Kondisi lapangan hanya (26,09\%) responden yang melakukan penyemprotan berdasarkan jumlah hama dilapangan. Berdasarkan wawancara dengan informan dari Dinas Pertanian menyatakan petani biasa menggunakan pestisida sebagai upaya pengendalian hama dan penyakit. Berdasarkan PP No. 6 Tahun 1995 tentang perlindungan tanaman pestisida merupakan salah satu sarana pengendali OPT (organisme pengganggu tumbuhan) oleh karena sifatnya yang berbahaya, maka 
penggunaan pestisida merupakan alternatif terakhir dan dampak negatif yang ditimbulkan harus ditekan seminimal mungkin. Sektor pertanian dapat berakibat terjadinya pencemaran air dan tanah, terutama dari penggunaan pupuk dan bahan kimia pertanian tertentu seperti: insektisida dan herbisida yang dapat berakibat pada pencemaran lingkungan yang serius (Sunu, 2001).

Dalam pengelolaan limbah (56,62\%) responden membakar limbah pertanian, dimana biomassa yang telah kering dikumpulkan dan dibakar langsung pada lahan, kemudian abunya dimanfaatkan sebagai pupuk organik. Walaupun keuntungan secara umum diperoleh, mudah dan murah namun akan merusak fisik dan biologi tanah, tanah menjadi padat dan bahan organiknya habis (Tan, 1994).

\subsubsection{Perilaku Masyarakat Dalam Kegiatan Penambangan Pasir dan Batu}

a. Pelaksanaan dan pengelolaan

Penambangan

Usaha penambangan yang dijalani adalah usaha penambangan rakyat yaitu usaha pertambangan dengan produksi $0-20 \mathrm{~m} 3$ per/hari/lokasi dan tanpa menggunakan mesin. Kelurahan Kalumbuk salah satu lokasi aliran sungai yang dilarang melakukan kegiatan penambangan. Hal ini sesuai PP No. 35 Tahun 1991 tentang sungai pada pasal 29 menyatakan dalam melakukan pengerukan atau penggalian serta pengambilan bahan galian-c pada sungai hanya dapat dilakukan ditempat yang telah ditentukan oleh pejabat pemerintah berwenang.

Berdasarkan Surat Keputusan Gubernur Tk.I Sumatera Barat No.5 Tahun 1993 tentang petunjuk pelaksanaan Perda No.6 Tahun 1992 tentang usaha penambangan galian-c dengan dengan ketentuan tidak menggunakan alat berat namun setelah
Pemda mengeluarkan Perda N0. 27 Tahun 2002 tentang usaha pertambangan bahan galian-c dan dilanjuti dengan Perda No.2 Tahun 2006 maka segala aktivitas galian-c pada daerah aliran sungai tidak lagi mendapatkan ijin dari Pemda.

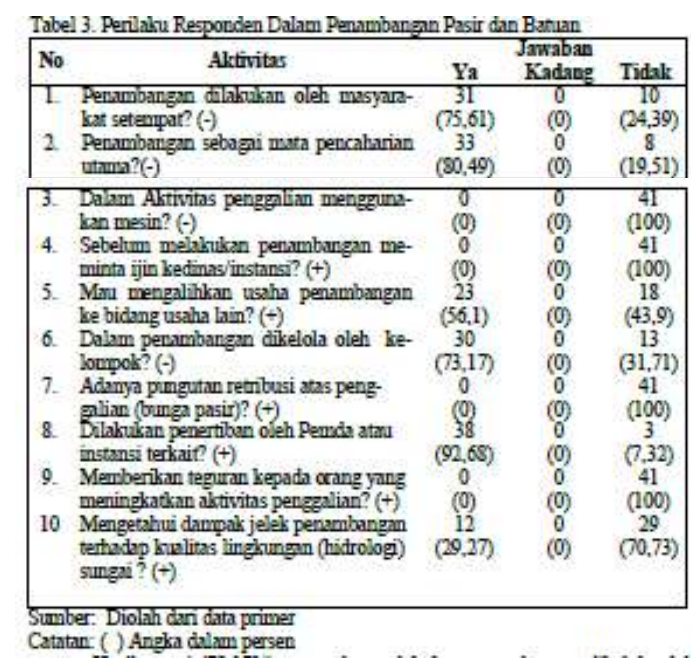

Hasil survei $(73,17 \%)$ responden melakukan penambangan dikelola oleh kelompok. Hal ini bertentangan dengan edaran peraturan yang dikeluarkan pemerintah daerah melalui Perda No.1 Tahun 2006 pada pasal 1, menyatakan "setiap orang atau badan usaha dilarang melakukan pengambilan bahan galian-c diatas bangunan sungai. Pungutan retribusi hasil produksi pasir dan batu hanya dilakukan pada daerah yang mempunyai SIPD (Surat Ijin Penambangan Daerah). Pungutan ini ada tahun 1987 dengan tarif iuran eksploitasi Rp.700,00 per ton. sejak tahun 1997 tidak lagi melihat kondisi sungai Batang Kuranji sudah sangat kritis dengan meningkatnya aktivitas masyarakat pada wilayah aliran sungai. (92,68\%) responden menyatakan adanya penertiban dilakukan Pemda, dan pengakuan ini diperkuat dengan pernyataan informan dari Dinas Pertambangan, pengawasan, dan penertiban aktivitas galian-c pada DAS Batang Kuranji dilakukan bekerjasama 
dengan aparat Satpol PP, Dinas Pekerjaan Umum, Dinas Pemukiman dan Prasarana Wilayah dan Dinas Pertambangan setiap 1 x 3 bulan. Jika ditemukan pelanggaran maka Pemda akan melakukan tindakan berupa pemasangan papan pengumuman larangan sehingga masyarakat umum mengetahuinya dan menutup jalan masuk ke sungai dengan pagar beton.

\subsubsection{Perilaku Masyarakat Dalam Pengelolaan Sampah Domestik}

a. Aktivitas Memilah dan membuang Sampah mayoritas $(72,22 \%)$ responden tidak melakukan pemisahan antara sampah kering dengan sampah basah dan (75\%) responden tidak melakukan pemisahan antara sampah organik dan sampah anorganik dirumah.

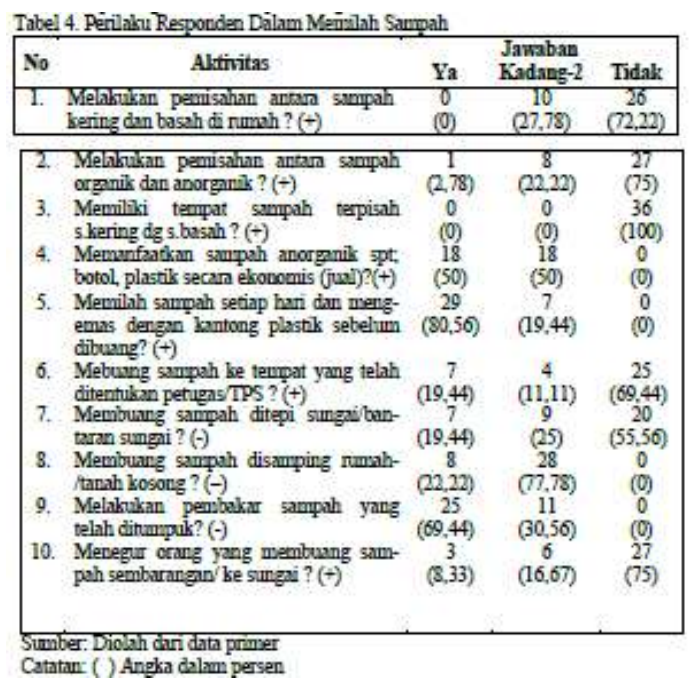

dikemas oleh responden ditumpuk pada suatu tempat kemudian dibuang. Ini tidak sesuai ketentuan yang tercantum dalam Perda N0. 5 Tahun 1985 tentang kebersihan pasal 16 ayat 1 , menyatakan sampah harian yang berasal dari rumah penduduk dibuang, ditumpuk atau letakan pada tempat penumpukan sampah yang telah ditetapkan sebagai tempat penumpukan sampah dan sekaligus merupakan pangkalan pengangkutan sampah oleh petugas dan ayat 3, yang menyatakan sampah yang menurut sifat dan ukurannya tidak mungkin dibungkus dalam kantong plastik harus dipotong dan diikat rapi sehingga memudahkan petugas untuk mengangkutnya. Untuk sampah anorganik seperti: botol, plastik, kaleng dan kertas mayoritas responden lebih memanfaatkannya secara ekonomis.

Pada lingkungan pemukiman sepanjang aliran sungai responden yang dekat TPS akan melakukan pembuangan sampah pada tempat yang telah diperuntukkan

$(19,44 \%)$. Namun pada lingkungan jauh dari TPS kebiasaan membuang

sampah di tempat kosong atau sungai yang berada disekitar lingkungannya. Hal ini disebabkan jumlah TPS yang minim dan jarak yang jauh dari rumah cenderung membuat warga mengelola sampah sendiri dengan cara membakarnya/terpaksa membuang sampah ketempat yang tidak dianjurkan seperti pada tempat kosong atau bantaran sungai. Hal ini terlihat $(44,44 \%)$ responden yang membuang sampah kebantaran sungai. Dan $(69,44 \%)$ responden melaksanakan aktivitas pembakaran sampah. Tidak seluruh warga yang sampahnya diambil petugas kebersihan sehingga masyarakat cenderung mengelolanya sendiri. Kecenderungan masyarakat membakar sampah karena belum paham tentang dampak pencemaran udara yang ditimbulkan dari pembakaran dan masyarakat masih belum merasakan dampak negatif dari kegiatan pembakaran. Pembakaran sampah akandikemas oleh responden ditumpuk pada suatu tempat kemudian dibuang. Ini tidak sesuai ketentuan yang tercantum dalam Perda N0. 5 Tahun 1985 tentang kebersihan pasal 16 ayat 1 , menyatakan sampah harian yang berasal dari rumah penduduk dibuang, ditumpuk atau letakan pada tempat penumpukan 
sampah yang telah ditetapkan sebagai tempat penumpukan sampah dan sekaligus merupakan pangkalan pengangkutan sampah oleh petugas dan ayat 3 , yang menyatakan sampah yang menurut sifat dan ukurannya tidak mungkin dibungkus dalam kantong plastik harus dipotong dan diikat rapi sehingga memudahkan petugas untuk mengangkutnya. Untuk sampah anorganik seperti: botol, plastik, kaleng dan kertas mayoritas responden lebih memanfaatkannya secara ekonomis.

Pada lingkungan pemukiman sepanjang aliran sungai responden yang dekat TPS akan melakukan pembuangan sampah pada tempat yang telah diperuntukkan $(19,44 \%)$. Namun pada lingkungan jauh dari TPS kebiasaan membuang sampah di tempat kosong atau sungai yang berada disekitar lingkungannya. Hal ini disebabkan jumlah TPS yang minim dan jarak yang jauh dari rumah cenderung membuat warga mengelola sampah sendiri dengan cara membakarnya/terpaksa membuang sampah ketempat yang tidak dianjurkan seperti pada tempat kosong atau bantaran sungai. Hal ini terlihat $(44,44 \%)$ responden yang membuang sampah kebantaran sungai. Dan $(69,44 \%)$ responden melaksanakan aktivitas pembakaran sampah. Tidak seluruh warga yang sampahnya diambil petugas kebersihan sehingga masyarakat cenderung mengelolanya sendiri.

Kecenderungan masyarakat membakar sampah karena belum paham tentang dampak pencemaran udara yang ditimbulkan dari pembakaran dan masyarakat masih belum merasakan dampak negatif dari kegiatan pembakaran. Pembakaran sampah akandikemas oleh responden ditumpuk pada suatu tempat kemudian dibuang. Ini tidak sesuai ketentuan yang tercantum dalam Perda N0. 5 Tahun 1985 tentang kebersihan pasal 16 ayat 1 , menyatakan sampah harian yang berasal dari rumah penduduk dibuang, ditumpuk atau letakan pada tempat penumpukan sampah yang telah ditetapkan sebagai tempat penumpukan sampah dan sekaligus merupakan pangkalan pengangkutan sampah oleh petugas dan ayat 3 , yang menyatakan sampah yang menurut sifat dan ukurannya tidak mungkin dibungkus dalam kantong plastik harus dipotong dan diikat rapi sehingga memudahkan petugas untuk mengangkutnya. Untuk sampah anorganik seperti: botol, plastik, kaleng dan kertas mayoritas responden lebih memanfaatkannya secara ekonomis. Pada lingkungan pemukiman sepanjang aliran sungai responden yang dekat TPS akan melakukan pembuangan sampah pada tempat yang telah diperuntukkan $(19,44 \%)$. Namun pada lingkungan jauh dari TPS kebiasaan membuang sampah di tempat kosong atau sungai yang berada disekitar lingkungannya. Hal ini disebabkan jumlah TPS yang minim dan jarak yang jauh dari rumah cenderung membuat warga mengelola sampah sendiri dengan cara membakarnya/ terpaksa membuang sampah ketempat yang tidak dianjurkan seperti pada tempat kosong atau bantaran sungai. Hal ini terlihat $(44,44 \%)$ responden yang membuang sampah kebantaran sungai. Dan $(69,44 \%)$ responden melaksanakan aktivitas pembakaran sampah. Tidak seluruh warga yang sampahnya diambil petugas kebersihan sehingga masyarakat cenderung mengelolanya sendiri.

Kecenderungan masyarakat membakar sampah karena belum paham tentang dampak pencemaran udara yang ditimbulkan dari pembakaran dan masyarakat masih belum merasakan dampak negatif dari kegiatan pembakaran. Pembakaran sampah akan menghasilkan banyak zat beracun antara lain: dioksin dan hidrokarbon yang bersifat karsinogenik (Otto, 2001). Tidak 
adanya teguran atau peringatan dari pihak berwenang meliputi: RT, RW dan kelurahan, menjadikan perilaku membuang sampah menjadi kebiasaan yang tidak dapat dihalangi. Berdasarkan laporan kualitas lingkungan dari Kementerian Lingkungan Hidup (2003), bahwa dari $20 \%$ sampah dibuang ke sungai, menyumbangkan 60- 70\% pencemaran sungai yang melintasi kota atau pemukiman padat kemudian pencemaran udara akibat pembakaran sampah yang merupakan permasalahan lain dari akibat penanganan sampah yang tidak ramah lingkungan. Dari penjelasan di atas dapat disimpulkan bahwa perilaku masyarakat dalam pengelolaan lingkungan termasuk kategori "sedang" serta "tidak baik". Hal ini dapat dilihat pada Tabel 10 dengan petunjuk pada Lampiran 8 .

\begin{tabular}{|c|c|c|c|}
\hline No & Perilala & Jangh (Jiwa) & Persen (\%) \\
\hline 1. & Balk & 6 & 6 \\
\hline 2. & Sedang & 48 & 48 \\
\hline & Tidak Baik & 36 & 36 \\
\hline & Total & 100 & 100 \\
\hline
\end{tabular}

Diantara penyebab kurangnya pemahaman masyarakat terhadap dampak kegiatan tersebut adalah tidak tersedianya sarana dan prasarana serta tindakan yang selama ini dilakukan sudah menjadi kebiasaan. Salah satu proses pembentukan perilaku adalah dengan condisioning atau kebiasaan dimana seseorang akan membiasakan diri untuk berperilaku seperti yang diharapkan sehingga terbentuk perilaku tersebut (Walgito, 2002).Perilaku dalam kegiatan pertanian terlihat masih kurang memahami bentuk teknologi pertanian yang berwawasan lingkungan, terlihat dari tindakan penggunaan pupuk anorganik dan pestisida serta tidak mengetahui dampak tindakan tersebut terhadap lingkungan. Hal ini jika dibiarkan akan berdampak pada pencemaran tanah, pencemaran perairan, dan matinya biota perairan.

Perilaku kegiatan penambangan terlihat masyarakat yang melakukan penambangan tidak memperoleh ijin (SIPD) dan tindakan tidak berwawasan lingkungan. Jika dibiarkan dapat merusak kondisi fisik sungai, erosi dan pelebaran badan sungai serta pencemaran kualitas air. Perilaku dalam pengelolaan sampah terlihat masyarakat masih membuang sampah ke sungai. Kurangnya kesadaran dalam aktivitas memilah sampah serta tidak adanya motivasi dari aparat pemerintah setempat bagaimana penanganan sampah yang baik.

\subsection{Faktor-faktor Yang}

Mempengaruhi Perilaku Masyarakat

Analisis mengetahui faktorfaktor mempengaruhi perilaku masyarakat digunakan analisis regresi berganda. variabel independen (X) adalah umur (X1), tingkat pendidikan (X2), jenis pekerjaan (X3), tingkat pendapatan (X4), pemahaman lingkungan (X5), komitmen pemerintah (X6) dan eksistensi undang-undang/ peraturan (X7). variabel dependen (Y) adalah perilaku masyarakat. Dengan menggunakan backward metode yakni dengan menghilangkan variabel tidak signifikan sehingga didapat persamaan regresi sebagai berikut:

$\mathrm{Y}=0,86-0,090(\mathrm{X} 1)+0,262(\mathrm{X3})+$ $0,571(X 5)+0,413$ (X6)

$R=0,583 \quad R 2=0,340$ Adj $R 2=0,312$ F-hitung $=12,241$

Untuk nilai $0,026 \mathrm{X} 3+0,571 \times 5+$ 0,413X6 adalah koefisien regresi yang menjelaskan bahwa setiap adanya penambahan 1 skor untuk masingmasing variabel X3, X5, dan X6 maka akan ada kenaikan skor masing-masing sebesar $0,262+0,571+0,413=1,2$ selanjutnya koefisien regresi $-0,090 \mathrm{X} 1$ 
menyatakan setiap penambahan karena nilai negatif (-) 1 skor maka akan mengurangi pernyataan perilaku sebesar 0,090. Selanjutnya, untuk melihat hubungan antara seluruh variabel bebas dengan variabel terikat dapat dilihat nilai koefisien korelasi (R) mencapai 0,583 yang setara dengan 58,3\%. Angka ini menunjukan bahwa korelasi mempunyai hubungan yang positif dan diatas angka 0,50 . Nilai koefisien determinasi (R2) $\mathrm{X}$ terhadap Y sebesar 0,340 atau $34 \%$ hal ini menunjukkan besarnya pengaruh variabel independen terhadap variabel dependen adalah 34\% sedangkan 66\% lainnya dipengaruhi oleh faktor lain yang dalam hal ini tidak diteliti.

Analisis ini diperkuat oleh uji $F$ atau uji ANOVA dalam variabel varian. Berdasarkan hasil pengujian analisis regresi variabel bebas terhadap perilaku diperoleh F-hitung sebesar 12,241 dengan tingkat signifikan $(0,00)$. Jika dibandingkan dengan nilai F-tabel untuk pengaruh variabel bebas terhadap perilaku dengan derajat bebas (4)(95) pada taraf kepercayaan 95\%. Diperoleh F-tabel sebesar 2,46. Hal ini menunjukan bahwa F-hitung lebih besar terhadap Ftabel $(12,241>2,46)$, yang menunjukkan bahwa sumbangan pengaruh variabel bebas terhadap perilaku sangat signifikan. Faktor-faktor yang paling dominan berpengaruh terhadap perilaku masyarakat dalam pengelolaan lingkungan di sepanjang daerah aliran sungai Batang kuranji dapat diketahui dengan melakukan analisis uji-t. Dari uji-t diperoleh nilai t-hitung untuk setiap variabel bebas adalah umur $(-1,984)$, jenis pekerjaan $(2,149)$, pemahaman lingkungan $(5,612)$ dan komitmen pemerintah $(3,404)$. Jika dibandingkan dengan nilai t-tabel pada pada taraf $95 \%$, diperoleh nilai t99.0,025 sebesar 1,980. Nilai t-hitung lebih besar dari t-tabel, merupakan variabel bebas yang dengan signifikan berpengaruh terhadap variabel terikat.

\subsubsection{Umur}

Umur merupakan salah satu indikator yang mempengaruhi cara berpikir seseorang dan erat kaitannya dengan perilaku seseorang. Pada umumnya usia muda lebih produktif bila dibandingkan dengan usia yang lebih tua. Ini berarti bahwa produktivitas kerja mula-mula meningkat sesuai dengan pertambahan umur. (Simanjuntak, 1986).

\begin{tabular}{|c|c|c|c|c|c|c|c|}
\hline \multirow{2}{*}{ Kategori } & \multicolumn{2}{|c|}{ I } & \multicolumn{2}{|c|}{ II } & \multicolumn{2}{|c|}{ III } & \multirow{2}{*}{ Total } \\
\hline & Jumlah & $\%$ & Jumlah & $\%$ & Jumlah & $\%$ & \\
\hline $0-19$ & 0 & 0,0 & 1 & 2,44 & 1 & 2,78 & 2 \\
\hline $20-29$ & 1 & 4,35 & 6 & 14,63 & 4 & 11,11 & 11 \\
\hline $30-39$ & 2 & 8.69 & 21 & 51,22 & 10 & 27,78 & 33 \\
\hline $40-49$ & 6 & 26,09 & 10 & 24.39 & 16 & 44,44 & 32 \\
\hline $50-59$ & 10 & 43,48 & 3 & 7,32 & 3 & 8,33 & 16 \\
\hline$>60$ & 4 & 17,39 & 0 & 0,0 & 2 & 5.56 & 6 \\
\hline Total & 23 & 100 & 41 & 100 & 36 & 100 & 100 \\
\hline
\end{tabular}

\section{KESIMPULAN DAN SARAN 5.1 KESIMPULAN}

Maka berdasarkan hasil penelitian ini dapat diambil kesimpulan sebagai berikut: 1. Pengaruh perilaku masyarakat secara umum dalam pengelolaan lingkungan adalah pada aspek pertanian kategori "sedang" terlihat pada indikator pengelolaan pertanian: dimana perilaku responden dalam pemupukan buatan dan pemberantasan hama, tindakan penggunaan pupuk buatan digabung dengan pupuk organik, tindakan pemupukan sesuai aturan pakai, dan penggunaan pestisida berdasarkan jumlah hama dilapangan. Pada indikator penambangan galian-c: dimana perilaku responden dalam pelaksanaan dan pengelolaan kategori "tidak baik" terlihat dari tidak adanya ijin dalam kegiatan penambangan, tidak adanya kontrol sosial dalam aktivitas penambangan pasir dan batu dan responden tidak mengetahui dampak penambangan terhadap kualitas lingkungan sungai. Dalam pengelolaan sampah: dimana perilaku responden dalam memilih dan membuang sampah 
kategori "sedang" terlihat dari tindakan responden dalam mengemas sampah menggunakan kantong plastik dan memanfaatkan sampah anorganik secara ekonomis.

2. Faktor yang mempengaruhi perilaku masyarakat dalam pengelolaan lingkungan adalah pemahaman tentang lingkungan kategori "tinggi", komitmen pemerintah dalam pengelolaan lingkungan kategori "rendah" dan jenis pekerjaan kategori "berhubungan dengan alam".

\subsection{SARAN}

1. Untuk mengurangi degradasi lingkungan pada daerah aliran sungai perlu dilakukan peningkatan pemahaman lingkungan melalui pembinaan, penyuluhan dalam rangka mewujudkan pemanfaatan lahan yang tidak menimbulkan dampak bagi hidrologi dan lingkungan.

2. Pemerintah harus mempunyai komitmen yang tinggi terhadap pengelolaan lingkungan melalui upaya pengawasan terhadap aktivitas masyarakat yang berhubungan langsung dengan daerah aliran sungai diantaranya melakukan koordinasi dengan masyarakat dan lembaga swadaya masyarakat dalam rangka mewujudkan manusia sebagai pembina lingkungan.

3. Perlu dilakukan penataan ruang berazaskan lingkungan disepanjang kawasan DAS terutama terhadap kawasan pemukiman, pertanian dan eksploitasi galian-c. Menurut perencanaan tata ruang kota Padang 2004-2013 kawasan berjarak 100 m kirikanan sungai sebagai kawasan resapan sungai.

\section{DAFTAR PUSTAKA}

Akmal. 2002. Model Sosialisasi Undang-Undang Hak Azazi Manusia Dalam Rangka Pemberdayaan Masyarakat Daerah Sumbar. Laporan
Penelitian. UNP bekerjasama dengan Dinas Pembinaan dan Penelitian Masyarakat. Padang.

Asdak, C. 2001. Hidrologi dan Pengelolaan Daerah Aliran Sungai. Gadjah Mada University. Hal $89-98$

Azwar, S. 2003. Sikap Manusia, Teori dan Pengukurannya. Edisi ke-2, Pustaka Pelajar. Yogyakarta. 198 hal.

Bappeda dan PSI-SDAL. 2004 Studi Pengelolaan Sumber Daya Alam"Analisis Potensi Pembangunan Waduk Kota Padang. Laporan PSI-SDAL Unand. Padang.

Badan Pusat Statistik Kota Padang. 2003. Padang Dalam Angka 2004. Kantor Statistik Kota Padang.

Hakim, N., M.Y. Nyakpa., A.M. Lubis., S.C.Nugroho., M.R. Saul., M.A. Diha.,

G.B.Homh daan Bailey. 1986. DasarDasar Ilmu Tanah. Universitas Lampung. Lampung.

Hasyim, L., Tiwan, C., Dadang,W. 2003. Pengelolaan Sampah Terpadu Sebagai salah Satu Upaya Mengatasi Problem Sampah di Perkotaan. Makalah PPS IPB.

Husein, H.M. 1995. Lingkungan Hidup, Masalah, Pengelolaan dan Penegakan Hukum. Bumi Aksara. Jakarta.

Keputusan Menteri Pertanian Nomor. 01/Kpts/SR.130/1/2006 tentang

Rekomendasi Pemupukan Untuk Tanaman Padi Sawah

Keputusan Menteri Pertanian Nomor. 473/Kpts/TP.270/6/1996 tentang Pengedaran dan Penggunaan Pestisida.

Mitchell, B., B. Setiawan., D.H. Rahmi. 2000. Pengelolaan Sumberdaya dan Lingkungan. Gadjah Mada University Press. Yogyakarta. 
Nazir, M. 1983. Metodologi Penelitian.

Penerbit Gramedia. Jakarta.

Peraturan Walikota Padang

Nomor 01 Tahun 2006 tentang

Larangan Melakukan Kegiatan

Pengambilan Bahan Galian

Golongan-C Pada Daerah

Aliran Sungai (DAS) Batang

Kuranji.

Peraturan Daerah Kotamadya Daerah

Tingkat II Padang Nomor 05

Tahun 1985 tentang Kebersihan

Dalam Kotamadya Daerah

Tingkat II Padang. 